\title{
PENGURANGAN KELEMBABAN UDARA MENGGUNAKAN LARUTAN CALSIUM CHLORIDE (CACL2) PADA WAKTU SIANG HARI DENGAN VARIASI SPRAYING NOZZLE
}

\author{
*Eflita Yohana, Yohanes Aditya Wisnu A. \\ Jurusan Teknik Mesin, Fakultas Teknik, Universitas Diponegoro \\ Jl. Prof. Soedharto, SH Tembalang, Semarang 50275, Indonesia \\ *E-mail: efnan2003@gmail.com
}

\begin{abstract}
ABSTRAK
Udara sangat penting dijaga kelembabannya agar nyaman dalam kehidupan manusia. Udara yang terlalu lembab dapat memicu tumbuhnya bakteri , korosi pada alat-alat logam, dan membahayakan kesehatan manusia. Udara terlalu kering juga menimbulkan ketidaknyamanan bagi kulit manusia.. Dehumidification merupakan proses untuk menurunan kelembaban udara yang terjadi di dehumidifier, dimana uap air diserap saat terjadi kontak dengan udara oleh liquid dessicant sebagai fluida kerja. Penelitian ini menguji pengaruh variasi nosel dan variasi konsentrasi terhadap kelembaban udara dengan menggunakan larutan $\mathrm{CaCl}_{2}$ sebagai liquid dessicant. Di bagian atas dari dehumidifier, liquid dessicant didistribusikan menggunakan spraying nozzle dan pada waktu bersamaan udara bergerak secara counter flow masuk ke dalam dehumidifier dari bagian bawah, dengan menggunakan induced fan yang terletak di atas spraying nozzle pada jarak tertentu. Dimensi nosel bervariasi sebesar 0,2 mm, 0,3 mm, 0,4 mm, dan 0,5 mm, sedangkan variasi konsentari $\mathrm{CaCl} 230 \%$, 40\%, dan 50\%. Debit aliran udara masuk dehumidifier dijaga konstan sebesar $2,35 \mathrm{~m}^{3} / \mathrm{min}$, temperatur masuk $\mathrm{CaCl}_{2}$ sebesar $18{ }^{\circ} \mathrm{C}$, serta perubahan kelembaban dan temperatur akan diukur menggunakan sensor suhu dan kelembaban DHT 11. Hasil penelitian menunjukan penurunan kelembaban udara lebih tinggi menggunakan spraying nozzle berdimensi 0,2 mm pada konsentrasi 50\% yaitu RH turun $13 \%$.
\end{abstract}

Kata kunci: Kelembaban, Liquid desiccant, dan Spraying nozzle.

\section{PENDAHULUAN}

Udara yang terlalu kering atau terlalu lembab memiliki dampak yang kurang baik. Untuk udara terlalu lembab dapat menyebabkan tumbuhnya bakteri terlalu cepat dan dapat menyebabkan korosi pada alat-alat yang terbuat dari logam. Untuk udara yang terlalu kering dapat menyebabkan gangguan kesehatan pada mata dan kulit [1].

Untuk hal itu, kelembaban udara yang tinggi dapat diatasi dengan cara menurunkan kelembaban udara yang juga disebut dengan dehumidifikasi. Terdapat dua metode untuk menghilangkan atau mengurangi kelembaban dari udara, yaitu refrigerant dehumidifikasi dan sorbent dehumidifikasi. Prinsip refrigerant dehumidifikasi adalah dengan menurunkan temperatur udara sampai dengan titik embunnya. Udara didinginkan dengan melakukan kontak pada koil pendingin hal ini disebut juga dengan sistem kompresi uap refrigerant. Namun sistem kompresi uap refrigerant ini boros energi, dalam prosesnya kompresi uap yang akan mempengaruhi kondisi global warming saat ini karena penggunaan refrigerant yang tidak ramah lingkungan dan penggunaan energy yang berasal dari pembakaran hidrokarbon, protokol Kyoto tahun 1997 mengharuskan negara industri mengurangi buangan gas rumah kaca dan karbondioksida penyebab global warming tersebut [2].

Prinsip sorbent dehumidifikasi dengan cara melewatkan udara lembab tersebut pada sebuah media penyerap kelembaban udara (sorbent). Sorbent dalam perkembangannya ada beberapa macam, antara lain absorbent dan adsorbent. Absorbent merupakan sorbent dimana dalam proses penyerapan uap akan berubah secara fisik dan kimia, biasanya berbentuk cairan seperti Lithium Chloride, Calsium Chloride, atau Ethylene Glycols. Sedangkan adsorbent merupakan sorbent yang tidak mengalamai perubahan bentuk fisik pada saat proses penyerapan dan biasanya berbentuk padat seperti silica gel atau alumina aktif [2].

Proses penyerapan cairan dari udara ke absorbent atau liquid desiccant ini terjadi saat udara dan larutan bersinggungan. Proses ini bergantung pada perbedaan tekanan parsial uap air diudara dan larutan. Sedangkan kesetimbangan tekanan uap dari larutan tergantung pada temperatur dan konsentrasinya. Proses penyerapan uap air yang terkandung di dalam udara (dehumidifikasi) ini terjadi jika tekanan uap air parsial pada liquid desiccant lebih rendah dari pada udara. Penurunan tekanan pada liquid desiccant ini sejalan dengan kenaikan konsentrasi dan kenaikan tekanan parsial uap air sejalan dengan kenaikan temperaturnya. Sedangkan untuk udara, tekanan uap air parsialnya akan naik sejalan dengan kenaikan temperatur udara keringnya dan kelembaban absolutnya. Salah satu variabel yang mempengaruhi dalam proses absorpsi uap air adalah debit liquid desiccant dari sistem penyemprotan liquid desiccant. $[3]$.

Pada penelitian sebelumnya yaitu, tentang transfer massa dan kalor pada dehumidification system dengan $\mathrm{Cu}$ ultrafine sebagai desiccant cair [4], penelitian tersebut menunjukkan bahwa penurunan kelembaban udara akan 
meningkat dengan menurunnya kecepatan udara dan pada debit desiccant yang tinggi. Pada kecepatan udara yang rendah waktu kontak udara dengan desiccant lebih lama, sehingga transfer massa yang terjadi semakin besar. Sedangkan pada debit desiccant yang tinggi proses penurunan kelembaban udara juga semakin besar yang dikarenakan massa alir yang besar dari desiccant sehingga desiccant yang kontak dengan udara akan semakin banyak. Ini berakibat terjadinya transfer massa yang lebih besar antara udara dan desiccant. Kemudian dalam penelitian dengan menggunakan aliran yang berbeda dalam solar desiccant cooling system [5], penelitian tersebut menunjukkan bahwa menggunakan aliran counter flow akan menyebabkan turunnya kelembaban yang lebih besar dibandingkan menggunakan aliran parallel flow.

Berdasarkan kedua penelitian sebelumnya tampak bahwa proses penurunan kelembaban udara pada liquid desiccant dehumidification system merupakan sebuah proses transfer massa dan kalor. Proses transfer massa dan kalor tersebut memerlukan terjadinya kontak antara udara dengan desiccant cair. Dengan debit udara yang konstan, maka perubahan laju desiccant, dalam hal ini adalah massa alir desiccant cair yang dikontakkan terhadap udara, apakah memberikan pengaruh yang signifikan terhadap penurunan kelembaban. Untuk itu dilakukan penelitian pengaruh variasi distribusi desiccant melalui variasi nosel terhadap penurunan kelembaban udara pada dehumidification system dengan menggunakan larutan $\mathrm{CaCl}_{2}$ sebagai liquid desiccant.

\section{METODOLOGI PENELITIAN}

Sistem instalasi pengujian, seperti yang terlihat pada gambar 1 terdiri atas dehumidifier tower, pompa, tangki liquid desiccant, house sample.

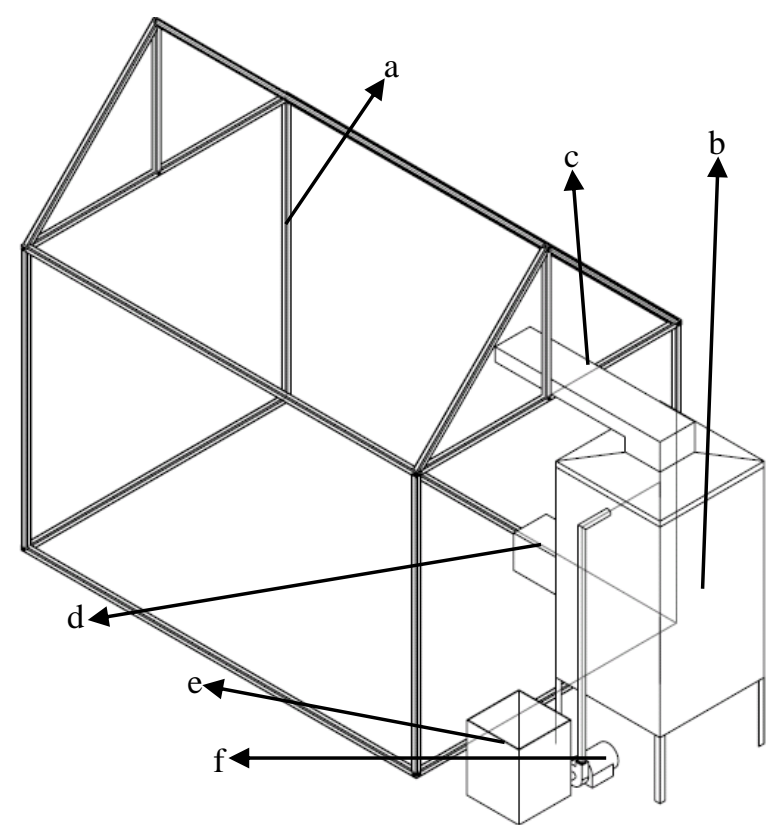

Gambar 1. Skema instalasi pengujian.

dimana:

a. Sample house

b. Dehumidifier tower

c. Outlet dehumidifier

d. Inlet dehumidifier

e. Tangki liquid desiccant

f. Pompa

Sample house memiliki dimensi 1,5 m x $1 \mathrm{~m}$ yang ditutup dengan menggunakan plastik, kemudian bagian inlet dan outlet dari dehumidifier tower dimasukkan ke dalam sample house tersebut. Dalam penelitian ini dehumidifier tower terbuat dari bahan acrylic dengan ketebalan $3 \mathrm{~mm}$. Dimensi yang digunakan ditampilkan pada gambar 2 dan gambar 3 dalam satuan mm. Pada gambar 2 ditampilkan dimensi dehumidifier tower tampak samping.

Tower memiliki tinggi $700 \mathrm{~mm}$ dan lebar $400 \mathrm{~mm}$ dan antara tower dan atap dari dehumidifier terdapat eliminator yang digunakan untuk mencegah liquid desiccant terbawa ke dalam ruangan.

Pada gambar 3 ditampilkan dimensi dehumidifier tower tampak depan yang memperlihatkan dimensi dari inlet dan outlet, serta memiliki lubang kecil berukuran $20 \mathrm{~mm}$ yang digunakan untuk mengeluarkan sisa liquid desiccant yang telah dispraying. 


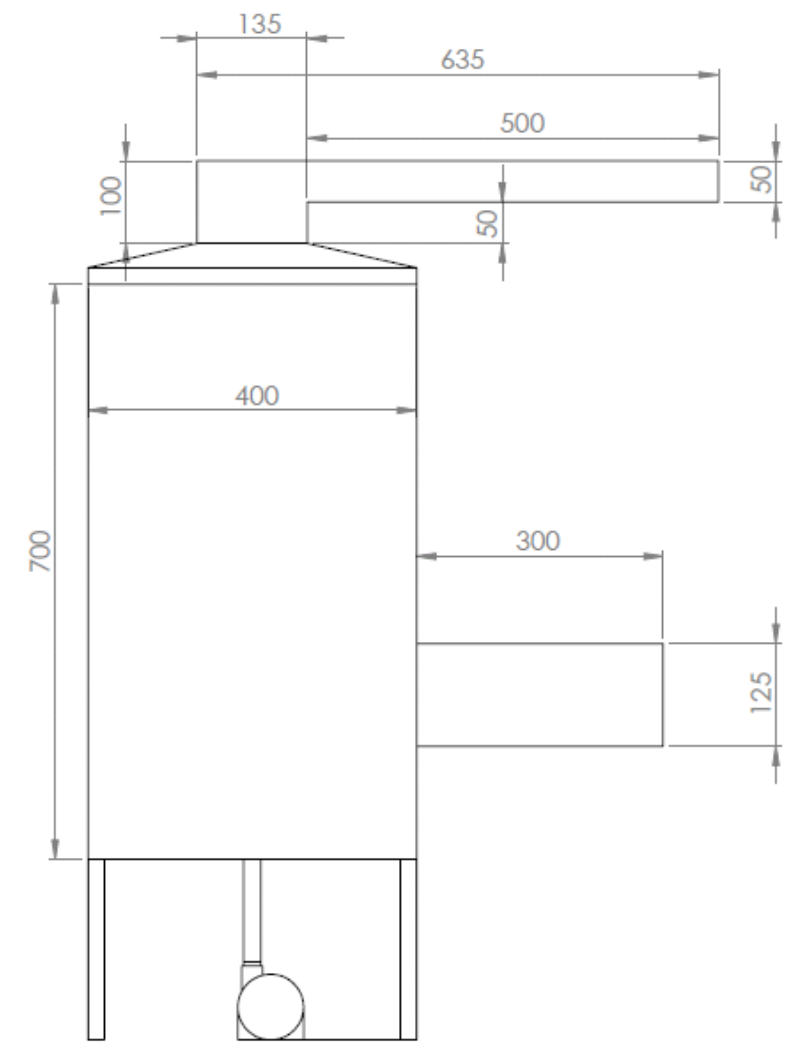

Gambar 2. Dimensi dehumidifier tower tampak samping.

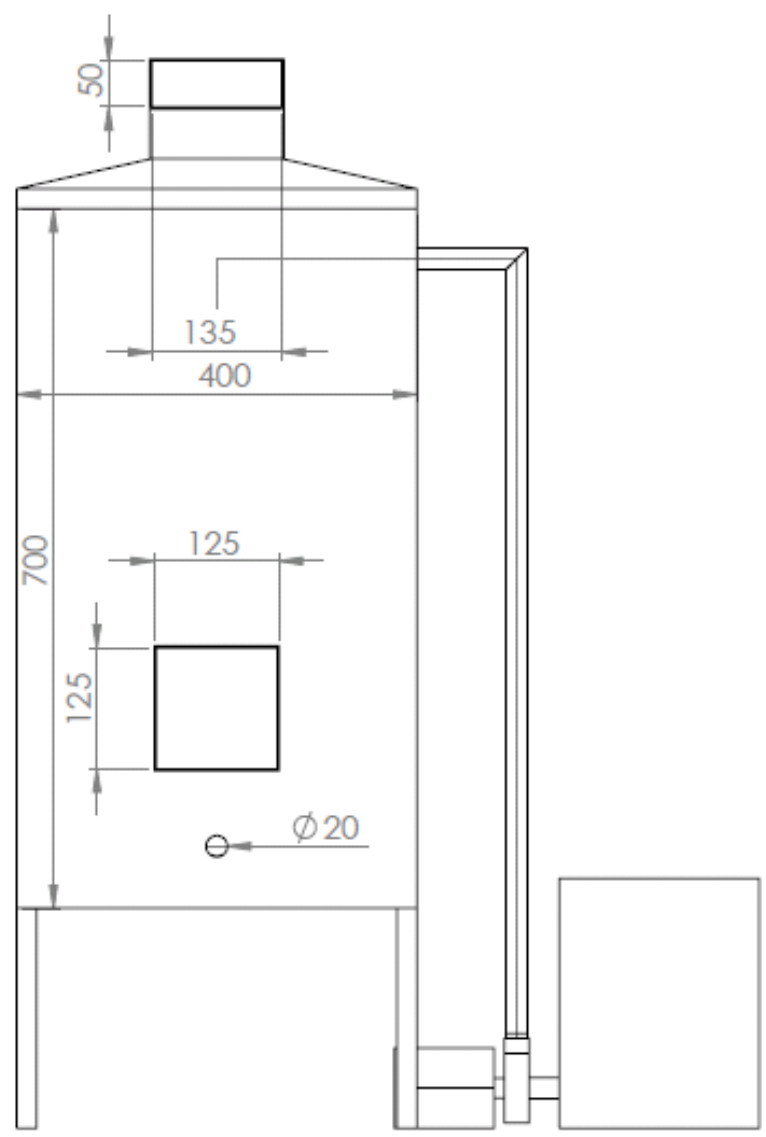

Gambar 3. Dimensi dehumidifier tower tampak depan. 
Penelitian dilakukan dengan memompa liquid desiccant $\mathrm{CaCl}_{2}$ dingin yang temperaturnya dijaga pada $18^{\circ} \mathrm{C}$ dari tangki penampung ke dehumidifier tower. Larutan $\mathrm{CaCl}_{2}$ yang digunakan divariasikan berdasarkan konsentrasinya yaitu $30 \%$, 40\%, dan 50\%. Kemudian di dalam dehumidifier tower, larutan $\mathrm{CaCl}_{2}$ akan didistribusikan menggunakan spraying nozzle seperti yang ditampilkan pada gambar 4. Nosel ini akan divariasikan berdasarkan diameternya, yaitu $0,2 \mathrm{~mm}, 0,3 \mathrm{~mm}, 0,4 \mathrm{~mm}$, dan 0,5 mm. Perubahan kelembaban dan temperatur yang terjadi di dalam sample house akan diukur menggunakan sensor DHT 11 yang dipasang pada mulut inlet dan outlet dehumidifier tower selama 20 menit dan diambil data pada waktu siang hari.

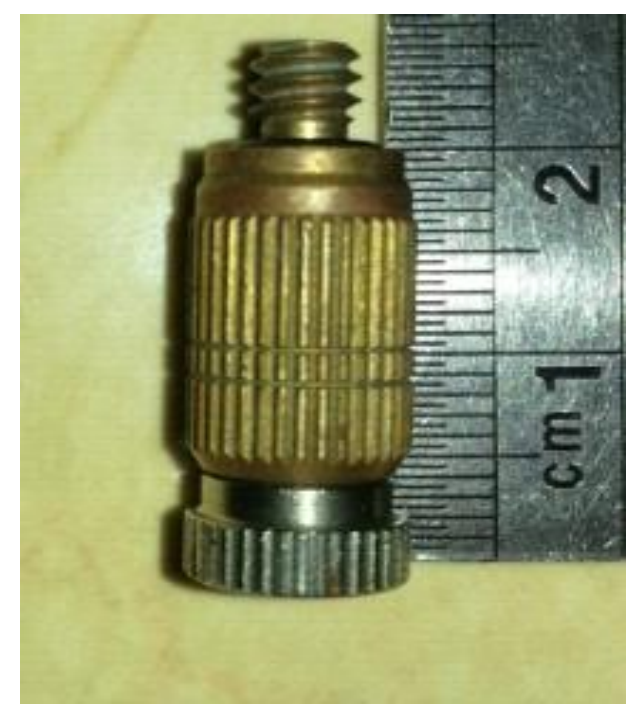

Gambar 4. Spraying nozzle yang digunakan pada dehumidifier tower.

\section{HASIL DAN PEMBAHASAN}

Efek kontak antara udara dan larutan $\mathrm{CaCl}_{2}$ dalam dehumidifier tower dievaluasi dari data yang telah diukur. Dalam penelitian ini, udara disirkulasikan dalam sample house menggunakan fan dan arah dari aliran larutan $\mathrm{CaCl}_{2}$ berlawanan terhadap udara. Hasil pengamatan relative humidity menggunakan larutan $\mathrm{CaCl}_{2} 50 \%$ yang memvariasikan nosel tiap pengujian ditampilkan pada Gambar 4.

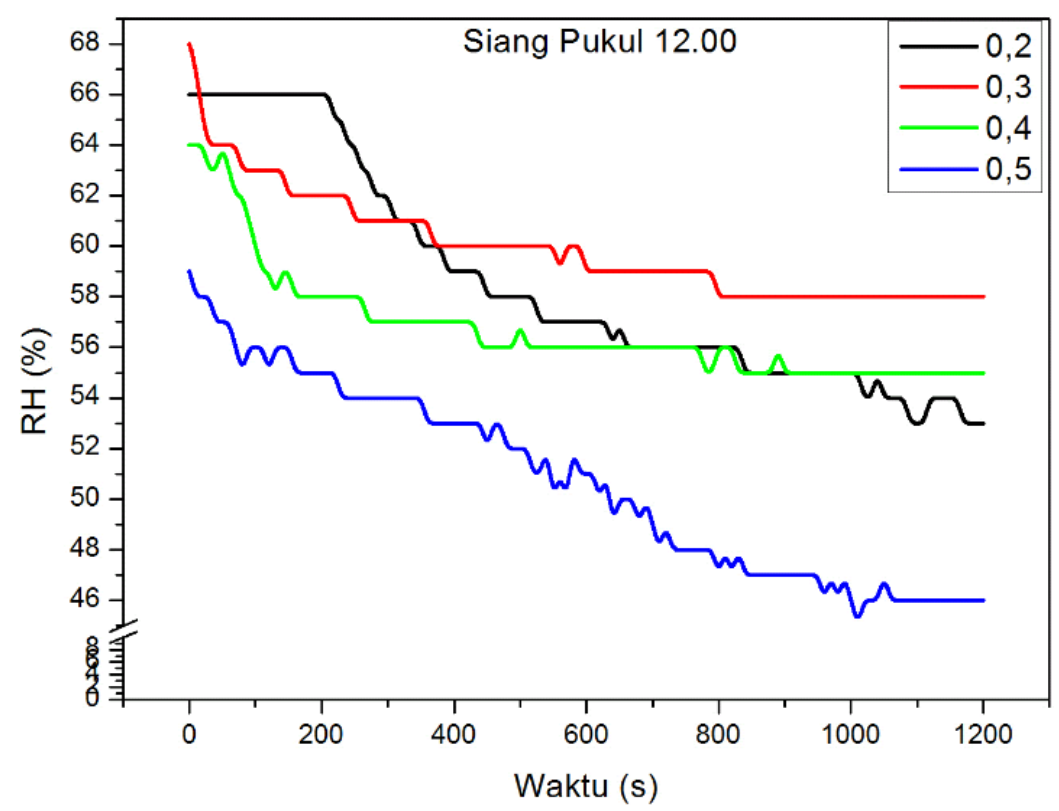

Gambar 4. Perubahan RH terhadap waktu menggunakan larutan $\mathrm{CaCl}_{2} 50 \%$.

Dari Gambar 4, penurunan relative humidity terbesar dapat dilihat pada nosel $0,2 \mathrm{~mm}$ dan nosel $0,5 \mathrm{~mm}$. $\mathrm{RH}$ turun dari $66 \%$ - 53\% Sedangkan penurunan relative humidity terkecil dapat dilihat pada nosel 0,5 $\mathrm{mm}$. RH turun dari $64 \%$ - 55\%. Pada Gambar 5 ditampilkan hasil pengamatan relative humidity menggunakan larutan $\mathrm{CaCl}_{2} \quad 40 \%$ yang memvariasikan nosel tiap pengujian. 


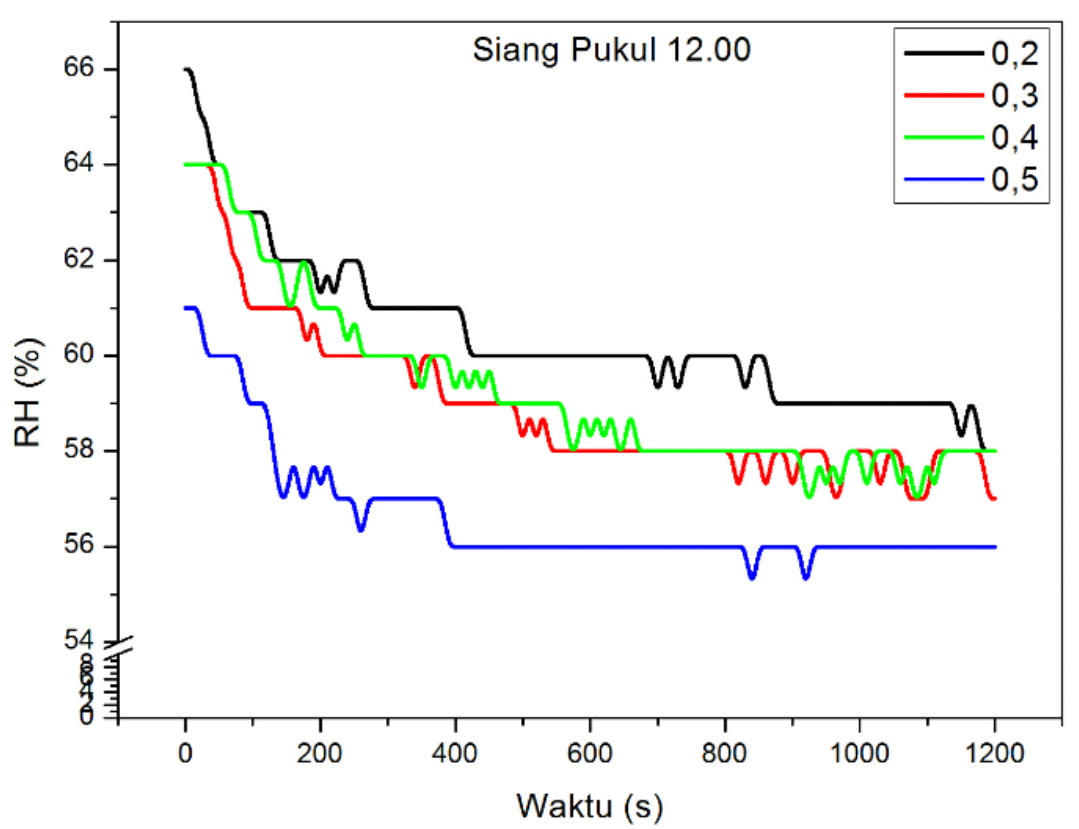

Gambar 5. Perubahan RH terhadap waktu menggunakan larutan $\mathrm{CaCl}_{2} 40 \%$.

Dari Gambar 5 penurunan relative humidity terbesar dapat dilihat pada nosel $0,2 \mathrm{~mm}$. RH turun dari $66 \%-58 \%$ Sedangkan penutunan relative humidity terkecil dapat dilihat pada nosel $0,5 \mathrm{~mm}$. RH turun dari $61 \%-56 \%$.

Dari Gambar 4 dan 5 dapat disimpulkan bahwa nosel 0,2 $\mathrm{mm}$ memiliki penurunan kelembaban yang besar dibanding variasi nosel yang lain. Hal ini dikarenakan nosel 0,2 $\mathrm{mm}$ memiliki butiran yang lebih halus, sehingga kontak antara udara dan liquid desiccant lebih besar, maka daya serap liquid desicant terhadap udara semakin besar. Walau ada kesalahan pengambilan data pada nosel $0,5 \mathrm{~mm}$ dengan konsentrasi liquid desiccant $40 \%$ dikarenakan adanya eror pada pada saat pengukuran sehingga data yang didapat menunjukkan kesamaan penurunan RH yaitu sebesar $13 \%$.

Pada Gambar 6 ditampilkan hasil pengamatan relative humidity menggunakan larutan $\mathrm{CaCl}_{2} \quad 30 \%$ yang memvariasikan nosel tiap pengujian.

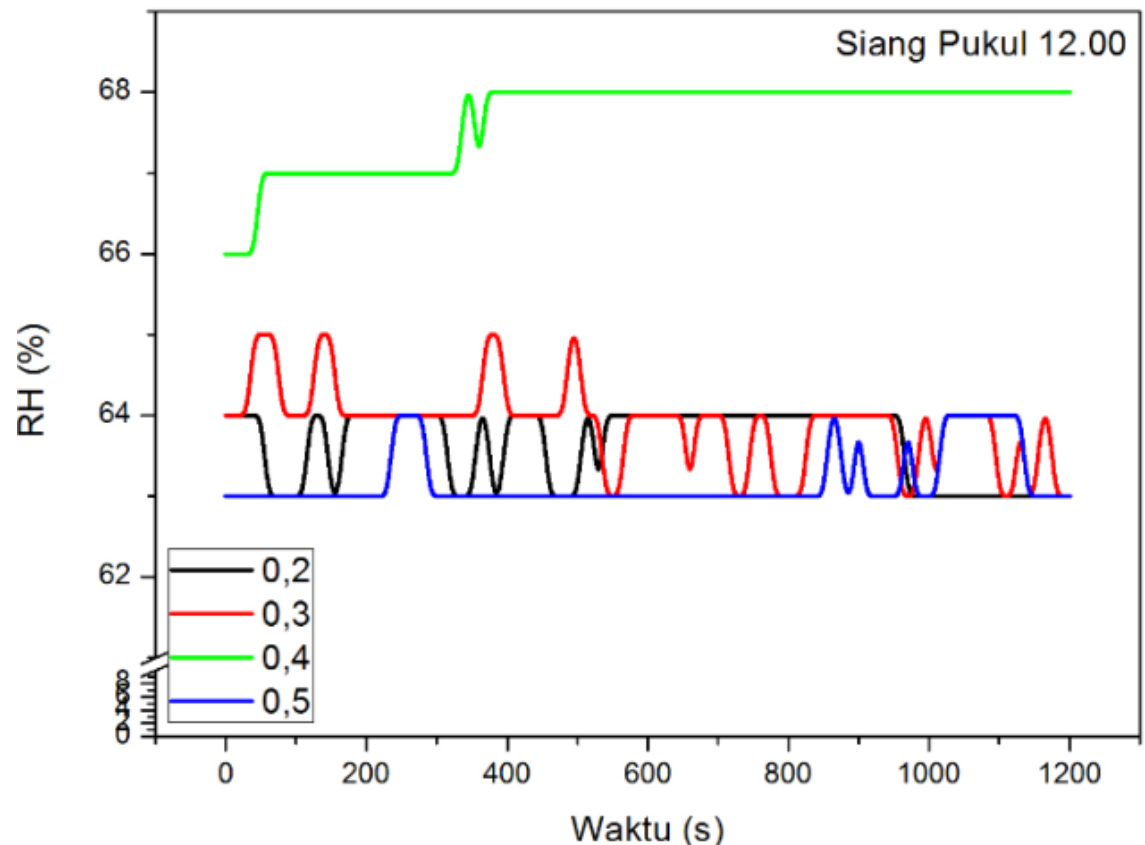

Gambar 6. Perubahan RH terhadap waktu menggunakan larutan $\mathrm{CaCl}_{2} 30 \%$.

Dari Gambar 6, larutan $\mathrm{CaCl}_{2}$ dengan konsentrasi 30\% mengalami ketidakstabilan karena perbandingan air dalam larutan $\mathrm{CaCl}_{2}$ yang besar. Sehingga kemampuan untuk menyerap uap air sangat kecil bahkan tidak bisa menyerap uap air di dalam udara.

Pada Gambar 7 - Gambar 10 ditampilkan pengaruh konsentrasi liquid desiccant terhadap kemampuan penurunan kelembaban. 


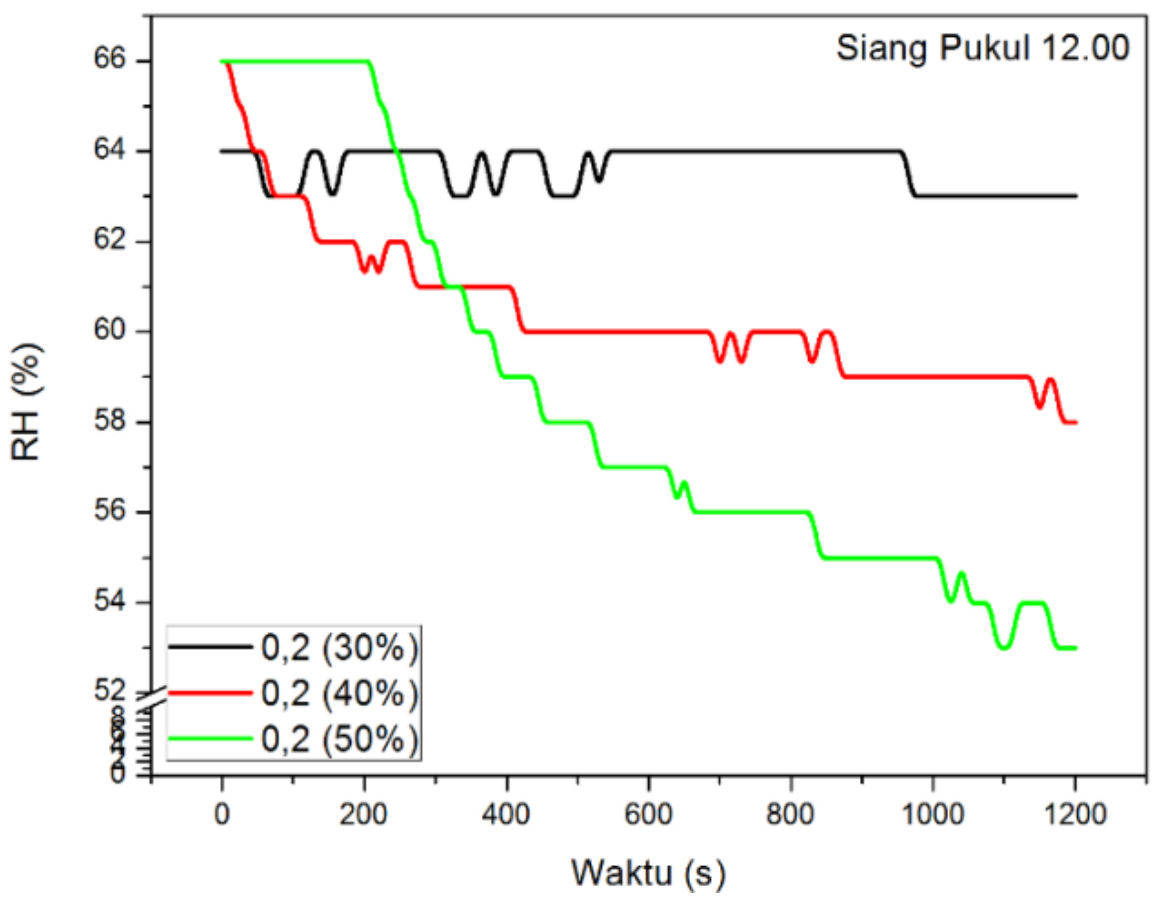

Gambar 7. Perubahan RH terhadap waktu menggunakan ukuran nosel 0,2 mm dengan variasi konsentrasi liquid desiccant.

Dari Gambar 7, penurunan relative humidity menggunakan liquid desiccant 50\% RH turun dari $66 \%-53 \%$. Menggunakan liquid desiccant $40 \%$ RH turun dari 66\% - 58\%. Dan menggunakan liquid desiccant $30 \%$ RH turun dari $64 \%-63 \%$.

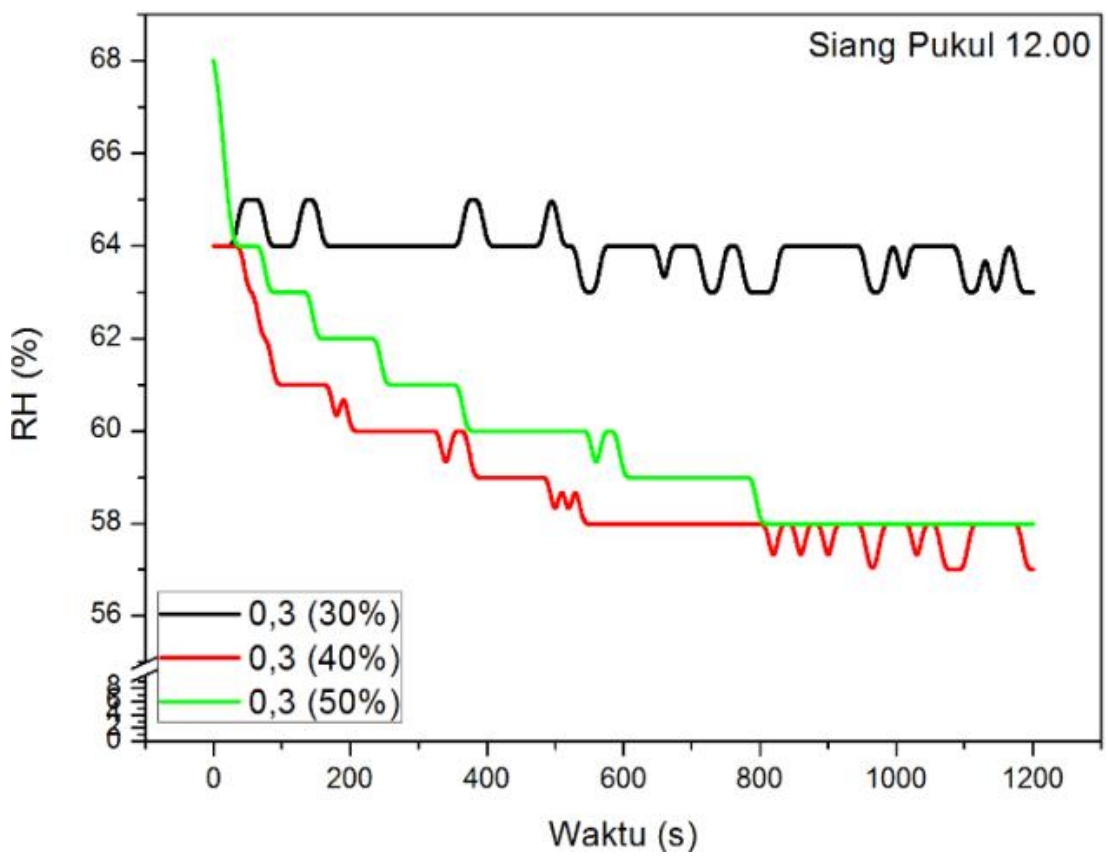

Gambar 8. Perubahan RH terhadap waktu menggunakan ukuran nosel 0,3 mm dengan variasi konsentrasi liquid desiccant.

Dari Gambar 8, penurunan relative humidity menggunakan liquid desiccant 50\% RH turun dari $68 \%-58 \%$. Menggunakan liquid desiccant 40\% RH turun dari 64\% - 57\%. Dan menggunakan liquid desiccant 30\% RH hanya berfluktuasi tercatat RH awal dan akhir pengujian adalah tetap $64 \%-63 \%$. 


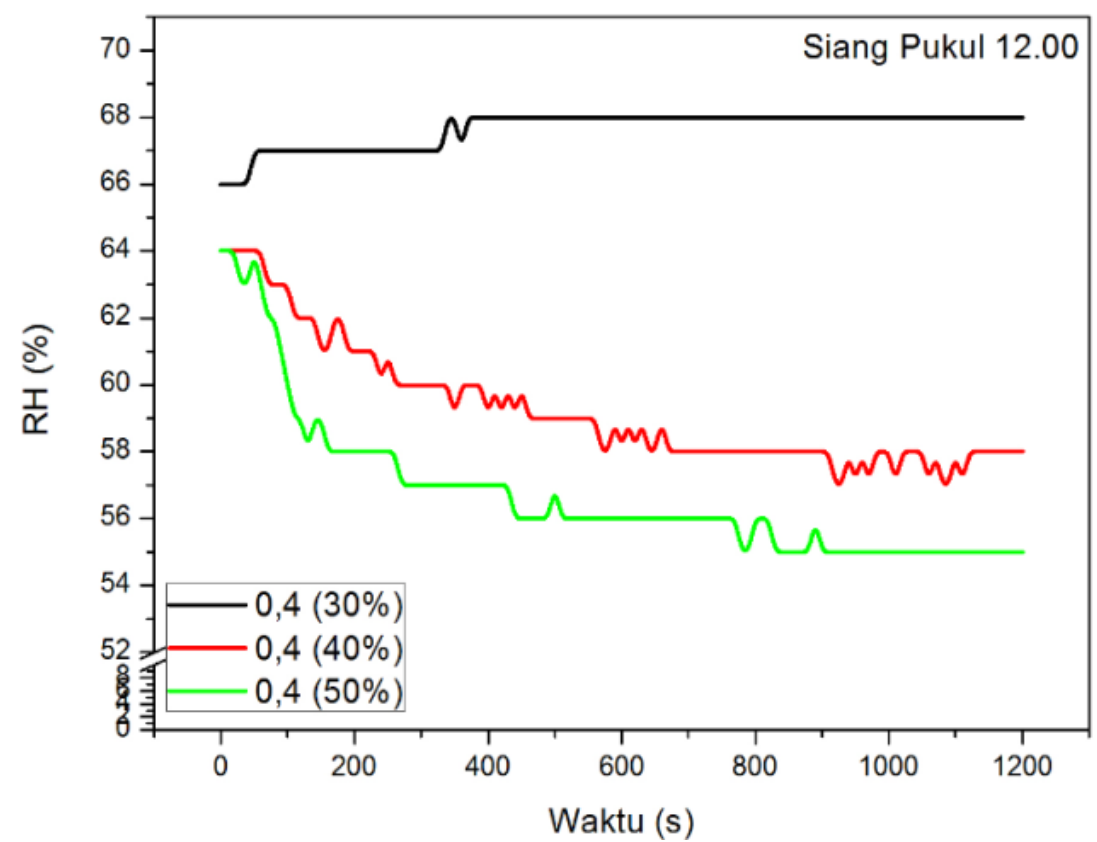

Gambar 9. Perubahan RH terhadap waktu menggunakan ukuran nosel 0,4 mm dengan variasi konsentrasi liquid desiccant.

Dari Gambar 9, penurunan relative humidity menggunakan liquid desiccant 50\% RH turun dari $64 \%-55 \%$. Menggunakan liquid desiccant 40\% RH turun dari 64\% - 58\%. Dan menggunakan liquid desiccant 30\% RH naik dari $66 \%-68 \%$.

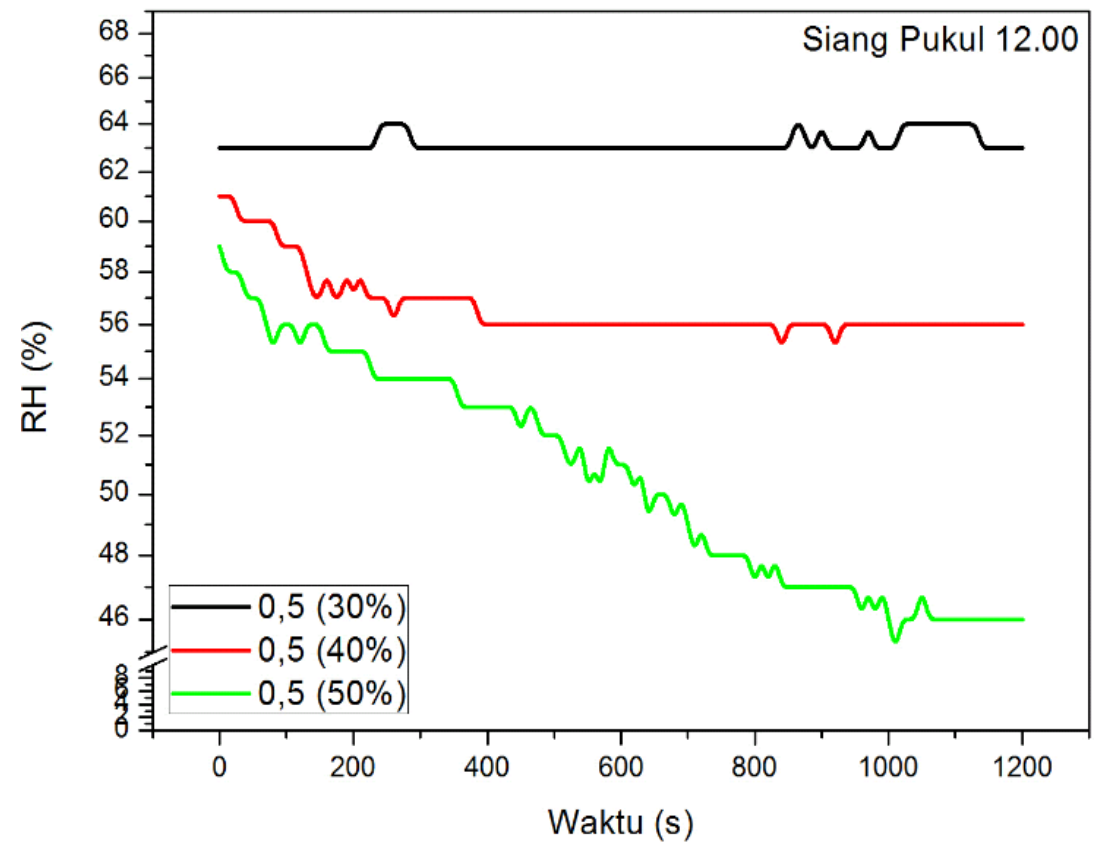

Gambar 10. Perubahan RH terhadap waktu menggunakan ukuran nosel 0,5 mm dengan variasi konsentrasi liquid desiccant.

Dari Gambar 10, penurunan relative humidity menggunakan liquid desiccant 50\% RH turun dari 59\% - 46\%. Menggunakan liquid desiccant 40\% RH turun dari 61\% - 56\%. Dan menggunakan liquid desiccant 30\% RH hanya berfluktuasi tercatat $\mathrm{RH}$ awal dan akhir pengujian adalah tetap $63 \%-63 \%$.

Dari Gambar 7 - Gambar 10, penurunan relative humidity terbesar dapat dilihat pada sistem yang menggunakan larutan $\mathrm{CaCl}_{2}$ dengan konsentrasi $50 \%$ dan penurunan relative humidity terkecil dapat dilihat pada sistem yang menggunakan larutan $\mathrm{CaCl}_{2}$ dengan konsentrasi 30\% Hal ini dikarenakan pada konsentrasi yang lebih besar, daya absorpsinya semakin besar. Kandungan uap air pada liquid desiccant berkonsentrasi besar tersebut lebih kecil, sehingga pada saat kontak antara udara dan larutan $\mathrm{CaCl}_{2}$, uap air cenderung terabsorpsi oleh larutan tersebut. 


\section{KESIMPULAN}

1) Dalam penelitian ini, konsentrasi larutan $\mathrm{CaCl}_{2} 50 \%$ memiliki penurunan $\mathrm{RH}$ terbesar, yaitu turun $13 \%$ dengan nosel 0,2 mm. Hal ini dipengaruhi oleh kemampuan penurunan kelembaban dalam konsentrasi liquid desiccant. Semakin besar konsentrasi liquid desiccant, semakin besar kemampuan untuk menurunkan kelembaban.

2) Dengan memvariasi distribusi liquid desiccant menggunakan spraying nozzle, semakin halus butiran yang dihasilkan, maka semakin besar kemampuan penurunan kelembabannya karena luas kontak antara udara dan liquid desiccant semakin besar. Dalam penelitian ini, mendistribusikan liquid desiccant menggunakan nosel $0,2 \mathrm{~mm}$ memberikan penurunan kelembaban yang paling tinggi dibandingkan variasi nosel yang lain.

\section{REFERENSI}

1. Brundrett, G. W, Handbook of Dehumidification Technology, Butterworths: London, 1987.

2. Stoecker, Wilbert F dan Jones, Jerold W, Refrigerasi dan Pengkondisian Udara, Erlangga, Jakarta, 1992.

3. Treybal, Robert E., Mass-Transfer Operations, third ed., McGraw-Hill International Edition, 1980.

4. Ali, A. et al., An investigation of heat and mass transfer between air and desiccant film inclined parallel and counter flow channels, International Journal of Heat and Mass Transfer 47, 1745-1760. Elsevier Science Ltd, 2004.

5. Eflita Yohana dan Choi Kwang-Hwan, A study and mass transfer with the different flows in a solar desiccant cooling system, Journal of the Korean Solar Energy Society, 1598-6411, 2010. 